УДК 343.54

DOI https://doi.org/10.32849/2663-5313/2019.10.27

\title{
Андрій Нєбитов,
}

докт. юрид. наук,

начальник Головного управління Начіональної полічіӥ в Київській області

\section{ЗАГАЛЬНОСОЩАЛЬНЕ ЗАПОБІГАННЯ СЕКСУАЛЬНІЙ ЕКСПЛУАТАЦІї}

Необхідність проведення всебічної роботи щодо запобігання протиправним діянням, пов'язаним із сексуальною експлуатацією, грунтується на вимогах законодавства України. Запобігання злочинам, пов'язаним із сексуальною експлуатачією, має стати головним напрямом протидії їй, оскільки саме виключення з неї дозволяє запобігти виникненню суспільно небезпечних наслідків. Під попередженням злочинності розуміють систему економічних, сочіокультурних, освітніх та правових заходів, що проводяться державними органами та громадськими організачіями для боротьби зі злочинністю та усунення ї̈ причин.

Запобігання сексуальній експлуатачї̈ на сочіальному рівні передбачає створення відповідноі правової підтримки. Начіональне законодавство України щодо запобігання сексуальній експлуатащіі створюється відповідно до міжнародних зобов'язань держави. Украйна приєдналася до міжнародних договорів та прийняла власні закони й положення, що слід враховувати в контексті загальної соціальної профілактики сексуальної експлуатації. Кожен із наявних правових актів у цій галузі відіграє певну роль у запобіганні иьому злу. Важливим аспектом попередження сочіальних злочинів є розробка та впровадження наукових програм з вивчення факторів ризику аномальної поведінки. Це проміжна ланка між теоретичним кримінологічним вивченням злочинності та практичною організачією профілактики, тобто безпосереднім виконанням теоретичних положень.

У сфері запобігання сексуальній експлуатаиї̈ на загальносоиіальному рівні ми зосереджуємось на вивченні правового забезпечення чієі роботи, оскільки інші загальносочіальні заходи щодо запобігання сексуальній експлуатаиії в основному проводяться під час здійснення загальних сочіальних заходів щодо запобігання злочинності загалом. Разом із тим удосконалення правового забезпечення запобігання сексуальній експлуатачії може розглядатися не лише в контексті вдосконалення законодавчого регулювання запобігання будь-якому злочину, а й в аспекті розробки та прийняття спечіальних правових актів, спрямованих на запобігання вчиненню певних дій, пов'язаних із сексуальною експлуатаиією людини. Законодавство Украйни у сфері запобігання сексуальній експлуатації є динамічним, що зумовлено особливостями суспільного життя. Це означає, що законодавство змінюється відповідно до сучасних вимог, щоб урегулювати різні правові відносини, пов'язані із запобіганням сексуальній експлуатачії та допомогою потерпілому з юридичної точки зору.

Ключові слова: запобігання злочинності, проституція, сексуальна експлуатація, сутенерство, торгівля людьми.

Постановка проблеми. Необхідність проведення комплексної роботи щодо запобігання протиправним діянням, пов’язаним із сексуальною експлуатацією, обгрунтовується вимогами чинного законодавства. Так, згідно зі ст. 1 Кримінального кодексу України [1], до його завдань належить правове забезпечення охорони прав і свобод людини і громадянина від злочинних посягань, а також запобігання злочинам. Як справедливо зауважує Є. О. Гладкова, тепер особливої гостроти набуває проблема запобіжної діяльності, яка перебуває у стані складних, суперечливих за своїм змістом, неоднозначних за наслідками процесів організаційного реформування, докорінної зміни суспільних відносин, що їі становлять [2, с. 101-102]. Запобігання зло- чинам, пов'язаним із сексуальною експлуатацією, повинно стати ключовим напрямом у протидії ним, адже саме недопущення їх вчинення дозволяє попередити настання суспільно небезпечних наслідків.

Науковому вивченню широкого спектру питань, пов'язаних із запобіганням подібним злочинам, приділяли увагу такі вчені, як Н. П. Бочкор, В. В. Василинчук, В. І. Воронов, В. Я. Горбачевський, О. М. Джужа, О. М. Смець, К. Б. Левченко, Л. Г. Ковальчук, I. Є. Конченкова, С. С. Чернявський та інші. Проте, незважаючи на це, проблема подолання сексуальної експлуатації залишається актуальною і сьогодні, що зумовлює доцільність продовження наукових досліджень у цій сфері. 
Мета статті. Розглянути особливості роботи правоохоронних органів та інших зацікавлених суб'єктів щодо запобігання сексуальній експлуатації на загальносоціальному рівні, а також оприлюднити власне бачення перспектив вирішення проблеми.

Виклад основного матеріалу. Загалом, під запобіганням злочинів розуміють систему заходів економічного, соціально-культурного, виховного та правового характеру, що здійснюються державними органами та громадськими організаціями для боротьби зі злочинністю та усунення іï̈ причин. Складовою частиною цих заходів є законодавство та практична діяльність правоохоронних органів, безпосередньо суду, що застосовує специфічні заходи боротьби зі злочинністю - кримінальне покарання [3, с. 343]. Попереджувальна діяльність має грунтуватись на певних принципах, провідне місце серед яких посідають [4, с. 114]:

- законність - дотримання вимог закону всіма без винятку суб'єктами;

- гуманність - захист гідності та інтересів людини шляхом очищення іï духовного світу від антисуспільних установок і орієнтацій, усунення чинників деформації особи;

- наукова обгрунтованість - використання форм, методів і засобів попереджувальної діяльності, розроблених та рекомендованих наукою;

- демократизм - широка участь у боротьбі зі злочинністю державних органів, громадських формувань та окремих громадян;

- диференціація - врахування специфіки факторів, що детермінують злочинність шляхом криміногенного впливу на особу, а також індивідуальних особливостей правопорушників;

- своєчасність - проведення превентивних заходів, які б не дали можливості вчинити злочин;

- плановість - здійснення діяльності за відповідною програмою, а не спонтанно;

- комплексність - використання різноманітних форм, методів і засобів попередження, спрямованих не тільки на злочинність, а й на ті соціальні, економічні, політичні, духовні та інші фактори, які її зумовлюють.

Під запобіганням злочинності в широкому розумінні мають на увазі історично сформовану систему подолання об'єктивних та суб'єктивних передумов злочинності, що реалізується шляхом цілеспрямованої діяльності всіх інститутів суспільства щодо усунення, зменшення та нейтралізації факторів, які детермінують існування злочинності та вчинення злочинів. У більш вузькому, прикладному, значенні запобігання злочинам являє собою діяльність, спрямовану на недопущення їх вчинення шляхом виявлення та усунення причин та умов, які сприяють їх вчиненню, здійснення впливу на осіб, схильних до їх вчинення. Обгрунтованою є позиція О. М. Литвинова щодо розуміння заходів загальносоціального (державного) характеру як сукупності ефективних заходів соціальноекономічного, правового, ідеологічного, організаційно-управлінського, культурновиховного змісту, спрямованих на подальший розвиток та вдосконалення суспільних відносин і усунення чи нейтралізацію детермінант злочинності [5, с. 111-117]. Заходи загального державного запобігання злочинності не обмежуються тільки предметом кримінологічної науки, оскільки спрямовані на вирішення більш широкого кола питань економічного, соціального, морально-психологічного та правового характеру [6, с. 145].

До основних цілей загальносоціального запобігання злочинності слід віднести подолання або обмеження криміногенно небезпечних суперечностей у суспільстві, поступове викорінення відомих ще з біблейських часів негативних явищ, створюваних політичними, економічними, психологічними, ідеологічними, міжнаціональними та іншими чинниками виникнення криміногенного потенціалу в суспільстві (економічні й політичні кризи, небезпечне майнове розшарування населення, необгрунтоване, навіть злочинне збагачення певних верств громадян, безробіття, затримка заробітної плати, існування на межі виживання переважної частини населення, занепад моралі, проституція, наркоманія, алкоголізм, безпритульність тощо). Ефективність загальносоціального запобігання злочинності може бути забезпечена розумною та цілеспрямованою соціально-економічною політикою держави [7, с. 19]. Загальносоціальні заходи пов'язані $з$ найбільш значущими та довгостроковими видами соціальної діяльності і здійснюються в процесі вирішення широкомасштабних соціальних завдань. Розв'язання суперечностей суспільного розвитку, його проблем і труднощів, помилок у соціальному управлінні є водночас економічною, політичною, ідеологічною, соціально-психологічною та правовою основою для усунення, послаблення і нейтралізації процесів та явищ, які детермінують злочинність. До загальносоціальних заходів запобігання злочинності якраз належать зміни в соціально-економічній сфері, спрямовані на підвищення життєвого рівня членів суспільства, поліпшення умов їхнього життя [8, с. 55-56]. 
Загальносоціальні заходи відзначаються масштабністю, всеохоплюючим і різностороннім характером, комплексністю і взаємозалежністю, безперервністю. Тут охоплюється великий спектр сфер життєдіяльності нації. Наприклад, у соціальній сфері - усунення різкого соціального розшарування суспільства; підтримка незаможних громадян; зміцнення сімейних підвалин; забезпечення належних умов для соціалізації особистості; подолання ії соціального відчуження; обмеження негативних наслідків безробіття, змушеної міграції людей, тощо. У правовій сфері - удосконалювання законодавства, прямо не націленого на запобігання злочинності, а такого, що має предметом правове регулювання різноманітних суспільних відносин (трудових, сімейних тощо), які, будучи нормативно не упорядкованими, можуть відігравати криміногенну роль [9].

Загальносоціальне запобігання злочинності - це насамперед комплекс перспективних соціально-економічних і культурновиховних заходів, спрямованих на подальший розвиток й удосконалення суспільних відносин і усунення або нейтралізацію причин та умов злочинності. Запобіжний потенціал цієї діяльності полягає в тому, що вона протидіє негативним явищам і процесам, які сприяють відтворенню або збільшенню кількості злочинів, стимулює законослухняну поведінку людини. Позитивний ефект отримується внаслідок продуманої соціальної політики, яка здійснюється не тільки і не стільки з метою безпосереднього запобігання злочинності. Вона спрямована перш за все на вирішення загальних економічних і соціальних завдань держави. Загальносоціальне запобігання злочинності зменшує соціальні суперечності, криміногенне протистояння різних верств населення, рівень безробіття, підвищує стандарт життя людей, створює необхідні умови для легалізованого одержання достатніх прибутків громадянами, сприяє побудові міцного фундаменту щодо нормального функціонування всіх соціальних сфер, виховання та контролю дітей і молоді, оздоровлення морального клімату в суспільстві, впровадження високих моральних цінностей у ньому, додержання демократичних засад та інше. Прогресивні соціальні програми спрямовані на утвердження законності, поваги до конституційних прав і свобод людини, зміцнення громадського порядку, дисципліни, на вирішення проблем поєднання громадських, виробничих, сімейно-побутових інтересів жінок і сім'ї, соціальної адаптації маргінальних верств населення тощо [10].

Під час проведення загальносоціальних заходів має бути забезпечена нормальна, тобто правомірна поведінка всіх членів суспільства. Здійснюється стримувальний від правопорушень вплив на всіх осіб, який має своїм джерелом соціальні, у тому числі правові, норми, відповідну поведінку державних органів, громадських організацій та окремих осіб [11, с. 319]. Науковці до загальних форм впливу відносять [9]:

- видання законодавчих актів;

- інформування широких верств населення через засоби масової інформації про відповідальність за злочини;

- покращення соціальних та економічних умов, що позначаються на життєдіяльності населення;

- розбудову державних інституцій, які ведуть боротьбу зі злочинністю.

Отже, запобігання сексуальній експлуатації на загальносоціальному рівні передбачає створення відповідного правового забезпечення. Національне законодавство України щодо запобігання сексуальній експлуатації створюється відповідно до міжнародних зобов'язань держави. Україна приєднується до міжнародних договорів, приймає свої закони, а також підзаконні документи, що слід розглядати в контексті загальносоціального запобігання сексуальній експлуатації. Кожен із чинних нормативно-правових актів у цій сфері відіграє певну роль у запобіганні цьому злу.

До основних 3 них відносимо Конвенцію про боротьбу з торгівлею людьми і з експлуатацією проституції третіми особами 1949 року, Конвенцію ООН проти транснаціональної організованої злочинності 2000 року (Палермська конвенція), яку доповнює Протокол про попередження i припинення торгівлі людьми, особливо жінками і дітьми, і покарання за неї, Конвенцію Ради Свропи про заходи щодо протидії торгівлі людьми 2005 року, Конвенцію Ради Свропи про захист дітей від сексуальної експлуатації та сексуального насильства 2007 року. Кожен із цих документів, незважаючи на зовнішню схожість, має свої особливості, зокрема: сфера застосування Конвенцій Ради Свропи більш широка порівняно з Протоколом ООН про попередження і припинення торгівлі людьми, особливо жінками і дітьми, і покарання за неї, бо охоплює всі форми торгівлі людьми, внутрідержавні або транснаціональні, пов'язані або не пов'язані з організованою злочинністю. Водночас Протокол ООН підписано і ратифіковано більшою кількістю країн, та він діє практично по всьому світі, а не тільки в певній його частині.

В Україні немає спеціального закону про запобігання сексуальній експлуатації, але правовідносини в цій сфері регламен- 
туються іншими законами, які регулюють різні аспекти протидії цьому злу. Це, передусім, закони України «Про захист суспільної моралі» та «Про протидію торгівлі людьми». Останній також охоплює питання пов'язані 3 наданням допомоги потерпілим від такої протиправної діяльності особам. Кримінальне законодавство України не визначає окремого злочину сексуальної експлуатації, проте передбачає відповідальність за протиправні діяння, пов'язані з нею. Насамперед це торгівля людьми, метою якої зазвичай виступає сексуальна експлуатація (ст. 149 Кримінального кодексу України), ввезення, виготовлення, збут і розповсюдження порнографічних предметів (ст. 301 Кримінального кодексу України), створення або утримання місць розпусти і звідництво (ст. 302 Кримінального кодексу України), сутенерство або втягнення особи в заняття проституцією (ст. 303 Кримінального кодексу України). Законодавство ще складається $з$ підзаконних документів, зокрема тих, які відображають рішення Уряду України щодо запобігання сексуальній експлуатації. Так, Кабінетом Міністрів України відповідними постановами затверджено Державну цільову соціальну програму протидії торгівлі людьми та Загальнодержавну програму «Національний план дій щодо реалізації Конвенції ООН про права дитини», які містять низку положень щодо запобігання сексуальній експлуатації на загальносоціальному рівні.

Важливим аспектом загальносоціального запобігання злочинності виступають розроблення й упровадження наукових програм з вивчення факторів ризику щодо поведінки, що відхиляється від норми Вивчення специфіки факторів злочинної поведінки є проміжною ланкою між теоретичним кримінологічним вивченням злочинності і практичною організацією запобігання, тобто безпосередньою реалізацією теоретичних положень [2, с. 105]. В Україні разом із представниками органів влади активну участь у формуванні державної політики щодо запобігання сексуальній експлуатації, насамперед дітей, беруть численні неурядові організації, зокрема Міжнародний жіночий правозахисний центр «Ла Страда - Україна» [12]. Державна політика щодо загальносоціального запобігання сексуальній експлуатації може реалізовуватись шляхом проведення таких заходів:

- освітня робота 3 молодими людьми та їхніми батьками в навчальних закладах, що може здійснюватись у межах варіативної частини навчальних програм, тобто факультативно;
- організація навчання представників органів державної влади 3 питань запобігання сексуальній експлуатації. Цей вид діяльності здійснюють органи державної влади переважно в тісній співпраці з громадськими та міжнародними організаціями. Можливе введення до програм підготовки, перепідготовки та підвищення кваліфікації педагогічних працівників інститутів післядипломної педагогічної освіти навчальних курсів 3 проблем запобігання сексуальній експлуатації;

- інформаційна та просвітницька діяльність, спрямована на підвищення рівня обізнаності 3 проблемою широкого кола громадян. Органи державної влади спільно з громадськими та міжнародними організаціями можуть випускати листівки та інформувати населення за допомогою біл-бордів.

\section{Висновки}

Проведене дослідження питання про запобігання сексуальній експлуатації на загальносоціальному рівні дає змогу дійти певних висновків. Так, запобігання сексуальній експлуатації на загальносоціальному рівні спрямовано не безпосередньо на недопущення конкретних фактів сексуальної експлуатації певними людьми, а на зменшення кількості вчинення протиправних діянь у цій сфері шляхом поліпшення соціальноекономічної ситуації в країні, покращання морально-психологічного і духовного складників життя громадян. Державна політика запобігання сексуальній експлуатації на загальносоціальному рівні передбачає подолання об'єктивних і суб'єктивних передумов для сексуальної експлуатації та реалізується шляхом цілеспрямованої діяльності всіх інститутів суспільства 3 усунення, зменшення та нейтралізації факторів, які детермінують існування таких явищ. Загальносоціальні заходи запобігання сексуальній експлуатації включають роботу за такими напрямами, як соціально-економічний, правовий, ідеологічний, організаційно-управлінський та культурно-виховний.

У запобіганні сексуальній експлуатації на загальносоціальному рівні акцент робимо на вивченні правового забезпечення такої роботи, адже інші загальносоціальні заходи запобігання сексуальній експлуатації переважно здійснюються шляхом проведення загальносоціальних заходів запобігання злочинності в цілому. Водночас удосконалення правового забезпечення запобігання сексуальній експлуатації може розглядатись не тільки в контексті удосконалення законодавчого регулювання запобігання будь-яким злочинам, а й в аспекті вироблення та прийняття спеціальних нормативно-правових 
актів, спрямованих на запобігання вчиненню певних дій, пов'язаних саме із сексуальною експлуатацією людини. Законодавству України у сфері запобігання сексуальній експлуатації властива динамічність, яка обгрунтована особливостями суспільного життя. Це означає, що законодавство змінюється відповідно до сучасних вимог, для того щоб з правової точки зору найбільш повно врегульовувати різні правовідносини, пов'язані із запобіганням сексуальній експлуатації та допомогою потерпілим особам.

\section{Список використаних джерел:}

1. Кримінальний кодекс України від 5 квітня 2001 р. ; набрав чинності 1 верес. 2001 р. Відомості Верховної Ради Украӥни (ВВР). 2001. № 25-26. Ст. 131.

2. Гладкова Є. О. Питання загальносоціального запобігання злочинності. Вісник Кримінологічної асоиіаиї України № 7 : збірник наукових праць / редкол. Т. А. Денисова, О. М. Джужа, В. П. Ємельянов та ін. Харків : Золота миля, 2014. C. $101-105$.

3. Юридический энциклопедический словарь / глав. ред. А. Я. Сухарев ; редкол. : М. М. Богусловский и др. 2-е идз., доп. Москва, 1987. 528 с

4. Кримінологія : підруч. для студ. вищ. навч. закл. / Джужа О. М. , Кондратьєв Я. Ю. Кулик О. Г. , Михайленко П. П. та ін. ; за заг. ред. О. М. Джужи. Київ : Юрінком Інтер, 2002. 416 с.
5. Литвинов О. М. Загальносоціальний вектор у механізмі протидії злочинності та фактори, що його обумовлюють. Вісник Харківського нащіонального університету внутрішніх справ. 2008. Вип. 41. С. 111-117.

6. Однолько I. В. Теоретичні засади запобігання злочинності. Юридичний вісник. Повітряне i космічне право. 2013. № 4. С. 141-145.

7. Голіна В. В. Запобігання злочинності (теорія і практика) : навчальний посібник. Харків Нац. юрид. акад. України, 2011. 120 с.

8. Кримінологія : навчальний посібник Джужа О. М. , Василевич В. В., Колб О. Г. та ін. ; за заг. ред. д-ра юрид. наук, проф. О. М. Джужи. Київ : Атіка, 2009. 312 с.

9. Профілактика злочинів : підручник / Джужа О. М. , Василевич В. В. , Гіда О. Ф. та ін. ; за заг. ред. д-ра юрид. наук, проф. О М. Джужи. Київ : Атіка, 2011. 720 с.

10. Кримінологія: Загальна та Особлива частини: підручник / Голіна В. В. , Головкін Б. М. , Валуйська М. Ю. , Лисодед О. В. та ін. ; за ред. В. В. Голіни і Б. М. Головкіна. Харків : Право, 2014. 513 с.

11. Йосипів А. О. Загальносоціальна, спеціально-кримінологічна та індивідуальна профілактиказлочинності: правові аспекти. Науковий вісник Львівського держсавного університету внутрішніх справ. Серія «Юридична». 2010. Вип. 1. С. 315-324.

12. Сексуальна експлуатація дітей в Україні: стан та заходи з протидії / Н. П. Бочкор, Л. Г. Ковальчук, І. Є. Конченкова та ін.; заг. ред. К. Б. Левченко, Л. Г. Ковальчук. Харків : Права людини, 2014. 64 с.

The necessity of carrying out comprehensive work on the prevention of unlawful acts related to sexual exploitation is based on the requirements of the legislation of Ukraine. Prevention of crimes related to sexual exploitation should be a leading focus in counteracting it, because it is the exclusion of it commission that allows to avert the onset of socially dangerous consequences. Crime prevention is understood as a system of economic, socio-cultural, educational and legal measures, carried out by state bodies and public organizations for combating crime and eliminating its causes.

The prevention of sexual exploitation at the social level presupposes the establishment of appropriate legal support. The national legislation of Ukraine on the prevention of sexual exploitation is being created in accordance with the international obligations of the state. Ukraine acceded to international treaties and adopted its own laws and regulations, what should be considered in the context of the general social prevention of sexual exploitation. Each of the existing legal acts in this area plays a role in preventing this evil. An important aspect of social crime prevention is the development and implementation of scientific programs to study risk factors for abnormal behavior. This is an intermediate link between the theoretical criminological study of crime and the practical organization of prevention, that is, the direct implementation of theoretical provisions.

In the prevention of sexual exploitation at the general social level, we focus on studying the legal support for this work, because other general social measures for the prevention of sexual exploitation are mainly carried out in the implementation of general social measures for the prevention of crime in total. At the same time, the improvement of legal support for the prevention of sexual exploitation can be considered not only in the context of improving the legislative regulation of the prevention of any crime, but also in the aspect of the development and adoption of special legal acts, aimed at preventing the commission of certain actions related to sexual exploitation of a person. The legislation of Ukraine in the field of prevention of sexual exploitation is not static, but dynamic, which is justified by the peculiarities of public life. This means that the legislation is being changed in accordance with modern requirements, in order to regulate the various legal relations related to the prevention of sexual exploitation and the victim's help from the legal point of view.

Key words: crime prevention, prostitution, sexual exploitation, pimping, human trafficking. 